\title{
Наташа Киш
}

\section{СИНТАКСИЧКО-СЕМАНТИЧКЕ КАРАКТЕРИСТИКЕ ДОПУНА ПРИДЕВА}

\begin{abstract}
Предмет анализе овог рада јесу семантичке и синтаксичке карактеристике допуна придева у савременом српском језику. Циљ рада јесте утврђивање семантичких функција допуна, односно семантичких, синтаксичких и прагматичких параметара који условљавају експликацију допуна одређеног семантичког типа и падежне форме. Анализа показује да је могуће издвојити пет основних семантичких функција допуна придева, у оквиру којих се разликује већи број семантичких подтипова допуна.

Кључне речи: придеви, комплементација, допуне, семантичке функције, синтакса, семантика, прагматика, српски језик.
\end{abstract}

In this paper we analyze the syntactic and semantic characteristics of adjective complements in contemporary Serbian. Our aim is to determine the semantic functions of these complements, i.e. to point to semantic, syntactic and pragmatic parameters that affect the choice of complements of a certain semantic type and form. The analysis shows that it is possible to single out six basic semantic functions of adjective complements with a large number of semantic subtypes.

Key words: adjectives, complementation, complements, semantic functions, syntax, semantics, pragmatics, Serbian language.

0. Однос комплементације, односно допуњавања који се успоставља у глаголским, именичким и придевским синтагмама ${ }^{1}$ одређен је првенствено рекцијским потенцијалом речи. Иако је глаголска рекција, као и рекција појединачних семантичких класа глагола била предмет многих истраживања и студија, то није случај када је у питању рекцијски потенцијал именица, а занемарљив је и број студија које се баве рекцијом придева и питањима њиховог допуњавања у србистичкој и широј словенској литератури (Ружић 2006: 232). Краћи преглед рекције и значењских типова придева представила је Владислава Ружић говорећи о допунским реченицама у савременом српском језику (2006: 234-243). Опсежно истраживање семантичких и морфосинтаксичких особености придева који захтевају експликацију, конкретизацију или употпуњавање свог значења представљено је у студији Дойуне йрияева у савременом срииском језику (Киш 2016). Издвојене су четири семантичке класе придева овог типа: придеви са значењем особине, придеви са значењем оgноса између два или више учесника у релацији, придеви којима се озна-

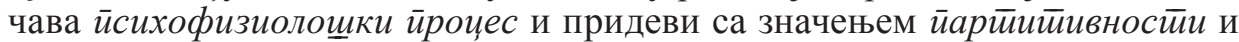
кванйификачије. Односе унутар придевске синтагме карактерише скалираност и одсуство чврстих граница при одређивању природе и врсте односа који се успостављају између управног и зависног члана. Благи прелази од

\footnotetext{
${ }^{1}$ Одређење синтагме као синтаксичке јединице као и односа који се унутар ње успостављају у нашој науци о језику поставио је Александар Белић, а посебно је важно истаћи његово тумачење улоге синтагме у служби постанка падежа. Видети детаљније о томе у: БЕлић 1998.
} 
одредбе или додатка до допуне, од онога што се сматра необавезним до онога што се сматра обавезним чланом синтагме указују на неопходност успостављања одговарајућих критеријума за категоризацију допуна и издвајање основних карактеристика процеса комплементације придева у савременом српском језику. „Како су придеви несамосталне речи, показало се да се у односу допуњавања њиховог семантичког садржаја као релевантни параметри морају укључити како њихово лексичко значење и значење зависног члана, односно допуне, тако и укупни синтаксичко-семантички контекст у којем се овај однос анализира, као и различити нејезички, односно прагматички параметри" (Киш 2016: 187). Стога су као релевантни критеријуми за одре-

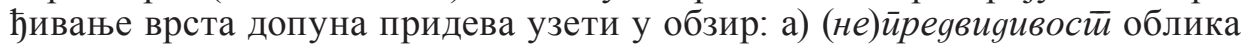
допуне условљена семантичким садржајем и синтаксичко-семантичким карактеристикама придева; б) (не)обавезносӣ појављивања допуне, односно могућност употребе придева са допуном или без ње; в) ирромена информа-

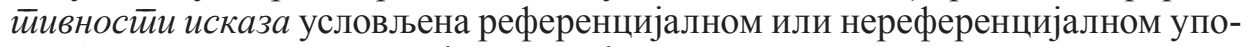
требом придева у ситуацији када појава допуне условљава промену семантичке класе којој придев припада као и значења читавог исказа у саставу чијег предиката је придев. Према овим параметрима могу се разликовати две врсте допуна придева: обавезне gойуне и факулйайивне gойуне.

Овом приликом пажњу усмеравамо на саме допуне, на њихове семантичке и синтаксичке карактеристике. Циљ ове анализе јесте да се издвоје остварене семантичке функције допуна, ${ }^{2}$ те да се покажу релевантне семантичке компоненте присутне у самој придевској синтагми, и најпосле да се виде прототипичне и мање фреквентне падежне форме у којима се реализују допуне придева. ${ }^{3}$ Сентенцијалне форме допуна, тачније допунске клаузе, при том неће бити посебно издвајане будући да је њихова појава очекивана када се допуном упућује на одређени реченични садржај, а семантичке карактеристике допунских клауза једнаке су карактеристикама номиналних облика допуна. ${ }^{4}$

${ }^{2}$ У овом раду неће бити посматран тип допуне према степену обавезности експликације будући да то није релевантно за семантичке функције допуна. Тако се у оквиру једног истог семантичког типа могу разликовати допуне према степену обавезности.

3 Теоријски и методолошки оквири овог рада нису засновани на теорији валентности иако се синтаксичко-семантичке карактеристике допуна придева доводе у везу са семантичким улогама у којима се појмови у позицији допуна реализују. О семантичким улогама видети у: ВСелОводОВА 2000.

${ }^{4}$ Истраживање које претходи овом показало је да иако се допунама веома често експлицира одређена радња или акција, само мали број придева добија искључиво сентенцијалну

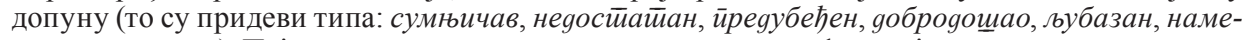
ран, нестирйлив). Поједине семантичке поткласе придева преферирају допуне у виду предлошко-падежних конструкција са девербативним или деадјективним именицама, где се само по изузетку појављује допуна у виду клаузе (то се односи на придеве са значењем особине испољене у одређеној ситуацији или при вршењу какве радње, особине типа способности, особине типа значаја или важности, особине која неког чини погодним или непогодним за остваривање одређеног циља, особине приписане неживом појму која га чини погодним или непогодним за одређену намену). У неколико семантичких поткласа уочено је да су ове две синтаксичке јединице у функцији допуне равноправно заступљене (у случају придева са значењем осећања или расположења усмереног ка неком референту, а изазваног каквом радњом објекта и са значењем става или мишљења). Придеви са модалним значењем пак примарно везују уз себе сентенцијалну допуну или инфинитив (Киш 2016: 196). 
Истраживање је спроведено на корпусу који сачињава 358 придева употребљених у преко 9000 примера преузетих из електронског Корйуса савре-

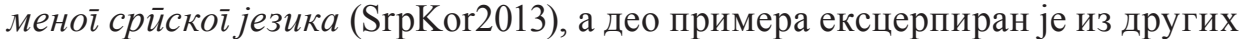
електронских извора, податак о њима наводи се уз сваки пример.

1. ДоПУНЕ СА ЗНАЧЕњЕм ОБЈЕКТА. Терминолошко решење за које смо се определили, одредивши ову групу допуна као допуне са значењем објекй $a$, треба схватити условно будући да смо као релевантне критеријуме истовремено узимали у обзир и њихове синтаксичке и семантичке карактеристике. Иако се лексичко-семантичко обележје транзитивности у традиционалним граматикама приписује првенствено глаголима, ${ }^{5}$ а њихове се допуне према синтаксичкој функцији у реченици одређују као објекатске, она се може довести у везу и са другим врстама речи, пре свега са именицама и придевима који се налазе у деривационој и семантичкој вези са глаголима. Ове именице и придеви преузимају рекцијски потенцијал глагола, ${ }^{6}$ те и оне уз себе везују допуне. С друге стране, обележје транзитивности може бити садржано

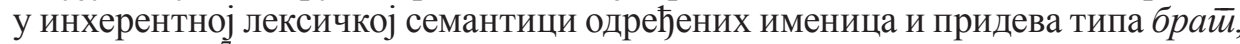

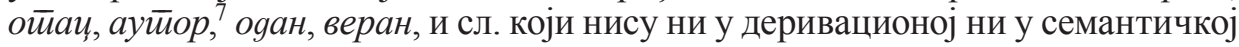
вези са глаголима. У прилог томе управо говори и истраживање представљено у монографији Дойуне йрияева у савременом срйском језику (Киш 2016).

Полазећи од синтаксичких и семантичких односа успостављених у реченици, узимајући у обзир лексичку семантику придева, издвојили смо неколико семантичких типова допуна које се у ширем смислу одређују као gойуне са значењем објекӣа.

1.1. ОБЈеКАТ УПУЋивАњА. Придеви којима се у конкретном контексту означавају различити психофизиолошки процеси, осећања и расположења, или пак особине, могу добити допуну којом је експлициран појам ка којем

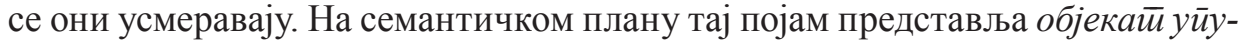

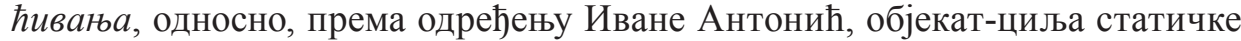
или динамичке усмерености (ПиПЕР и др. 2005: 185). На основу морфосинтаксичких обележја и семантичких односа успостављених у процесу комплементације придева, ${ }^{8}$ издвојили смо неколико подтипова ове врсте допуна.

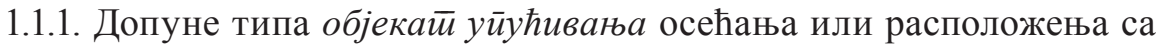
обележјем живо(+/-) добијају придеви који денотирају ситуацију у којој носилац психофизиолошког процеса у позицији граматичког субјекта има ознаку живо(+). У процесу комплементације овог типа придева обавезно је

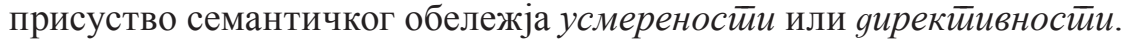

${ }^{5} \mathrm{O}$ транзитивности, односно о глаголском роду као једном од категоријалних својстава глагола видети у: СтЕВАНОВИЋ 1989; СТАНОјчић и др. 1989; ПиПЕР и др. 2005; ПиПЕР - КЛАЈн 2013.

${ }^{6}$ Владислава Ружић наводи да се рекција именица и придева који су у деривационој или семантичкој вези са глаголима може сматрати изведеном у односу на примарну глаголску (ПиПеР и др. 2005: 547).

${ }^{7}$ Од седамдесетих година двадесетог века прелазност, односно транзитивност почиње да се посматра као особина одређених семантичких група именица. Детаљније о томе видети

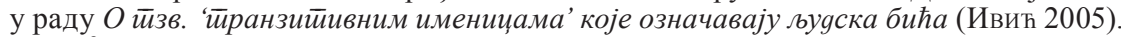

${ }^{8}$ Комплементација придева могућа је само када се придеви налазе у позицији лексичког језгра предиката. 
- Као протопипична форма допуне појављује се слободни датив ${ }^{9}$ или датив са предлогом пРЕмА ${ }^{10}$ (уз придеве типа болећив, милосрgан, неосейлив, веран, лојалан, ирреgан и сл.).

Одувек сам био болећив ирема свему што је старо.

Такав је заиста био и честити саветник де Ла Жакијер: милосрдан иррема сиромащнима...

... та је жена ... увек па и сада сва потпуно предана саgащњем ииренуйку и йослу који је пред њом...

А опет, осећала сам да бих морала да будем лојална свом оиу...

Објекай уйућивања експлицира се и уз придеве са значењем особине (придеви типа безобзиран, великоgущан, дарежльи, неискрен, неувиђаван, обзиран). Придеви ове семантичке поткласе тек употребљени са објекатском допуном имплицирају да се носилац особине „понаша на одређени начин” према некоме. Допуном у облику датива са предлогом пРЕмА ${ }^{11}$ исказује се појам, по правилу са семантичким обележјем живо $(+)$, према којем се усмерава одређени вия йонащања. ${ }^{12}$

Оштар је и безобзиран йрема ірещницима. [ $\rightarrow$ понаша се безобзирно йрема ірещничима]

- Допуна у форми генитива са предлогом спрам (уз придев настиројен ${ }^{13}$ ) и предлошким изразом у поглЕдУ (уз придев расйоложен). ${ }^{14}$

Јер, његови су филмови често исувише лични, бурлескни и критички настро-

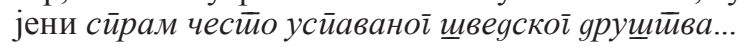

${ }^{9}$ Одређујући синтаксичко-семантичке карактеристике објекатског датива Ивана Антонић истиче да се ради о допунама глагола различитих семантичких класа, именица и придева који у инхерентној лексичкој семантици имају семантичко обележје директивности. Уколико се ради о транзитивним глаголима, онда датив има функцију индиректног објекта, док је у осталим ситуацијама у питању експликативна семантичка допуна „у својству, у најширем смислу схваћеног, објекта-циља статичке или динамичке усмерености” (2004: 77). нић 2011

${ }^{10} \mathrm{O}$ конструкцијама са предлогом премА у савременом српском језику видети у: Анто-

${ }^{11}$ Овај датив Ивана Антонић одређује према семантичко-синтаксичким карактеристикама као експликативни. Он се појављује уз одређене придеве (блай, gобар, gарежљив, љубазан,

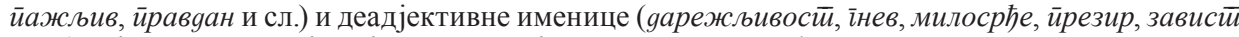
и сл.) којима се исказује појам према којем су усмерена осећања, особине или расположења: добар је йрема мени, праведан је йрема Ђаџима, строг је йрема gеии (2004: 84; 2005: 187). Истовремено, и датив уз глаголе типа оgносийи се, йонащайи се и одговарајуће девербативне именице, уз обавезно присуство квалификативног детерминатора, ауторка одређује на исти

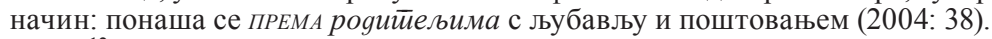

12 Придеви са значењем осећањ $а$ или расйоложељ $a$ као допуну везују уз себе појам са ознаком живо(+/-) према којем се дато осећање или расположење упућује. Они су немаркирани у погледу начина њиховог испољавања. С друге стране, придевима са значењем особине појма са обележјем живо(+) исказује се особина испољена у односу на неку особу или особе. Ови придеви маркирани су у погледу начина испољавања особине, односно имплицирају одређени начин понашања који се усмерава према некој особи.

${ }^{13}$ Придеви насйројен и расйоложен захтевају присуство детерминатора квалификативног типа.

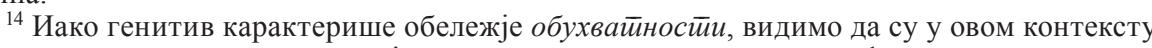
посматране генитивне конструкције синонимне предлошком дативу: филмови су критички настројени иррема честио усииваном щввесском ярущйву; оптимистички је настројен ирема изборним резулиеатиима. 
... изјавио је јуче, ... , да је „оптимистички расположен у йойлеgу изборних резулйайа"...

- Допуна у форми акузатива са предлошким изразом у односу на (уз придеве типа корекйан, независан, немилосряан).

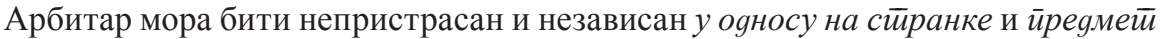
cйора.

... врхунски су професионалци, увек су били коректни у оgносу на Србе...

- Допуна у форми инструментала са предлогом СА ${ }^{15}$ уз придеве са значењем особине типа іруб, добар, искрен, љубазан, нељубазан, учйив, уздржан, фамилијаран. Иако ова конструкција у површинској структури не садржи

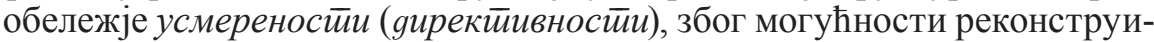
сања глагола „понашати се на одређени начин“ у семантичкој бази придева употребљених у овом синтаксичко-семантичком контексту, допуне овог типа могу се одредити као објекат упућивања.

Знате да ја никад нисам сувише учтива са тиаквим љуgима. [ $\rightarrow$ је се никада не понашам сувише учтиво са тйаквим љуудима]

1.1.2. Као засебан подтип издвајају се допуне групе придева са значењем

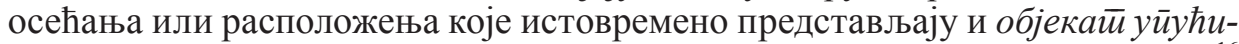
вања и каузайор, изазивач датог осећања или психофизиолошког процеса. ${ }^{16}$ У овом случају остварује се двосмерни однос између носиоца осећања или расположења са обележјем живо $(+)$ и појма у функцији допуне који може имати обележје живо(+/-).

- Допуна се по правилу реализује у облику акузатива са предлогом нА (уз придеве типа їаgљив, љубоморан, љуй, сажаљив, слаб, $\overline{н е в а н, ~ з а в и-~}$

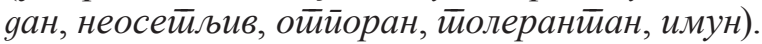

Нисам гадљив на велике тиираже и йойулизам.

Мислим да би већина била љута на снимайеља када би знали да је баш њих ухватио у објектив.

Госпођи Анђи Предић шаље писмо у Италију „завидан на боїайим їалеријама, музејима, ирквама".

Деца нетолерантна на храну често су немирна.

... даваће вам знаке рукама и ногама, јер Жил је осетљив на Ені̄лезе, забога, па то сви знају, Жил мрзи Енглезе.

Чак ни најелитнија служба безбедности на свету није имуна на сажаљење према богаљима.

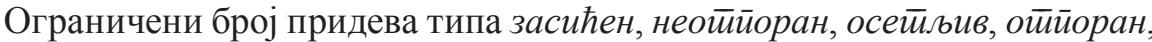

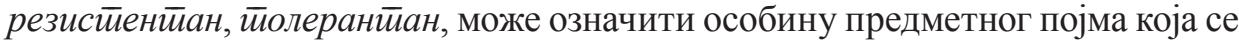
упућује према референту у функцији објекатске допуне.

${ }^{15}$ Инструментал са предлогом СА појављује се као допуна придевима којима се означава прагматичка ситуација у којој агенс испољава позитивно или негативно вредновано понашање према пасивном учеснику исказаном у инструменталу, а ова конструкција може се заменити дативом блокираним предлогом пРЕмА (ПиПЕР и др. 2005: 246-247).

${ }^{16}$ Михаило Стевановић наводи да је већина медијалних повратних глагола који означавају унутрашња стања или расположења непрелазна, али да има и неправих прелазних. Ови глаголи добијају као допуну неправи објекат који је заправо изазивач датог стања (1961-1962: 34-37). 
На амбалажи мора бити наведено да је заштитни производ фотостабилан и отпоран на воgу.

- Придеви типа нехајан и йасиониран добијају допуну у акузативу са предлогом зА, док придеви луg и йохлейан могу имати допуну у инструменталу са истим предлогом.

Они који о овоме уопште не размишљају, то су они хладни, незаинтересовани, нехајни за яуховне истиине...

Нема друге тако брзе и тако снажне промене - рече он - која би частољубива младића начинила похлепним за новцем.

1.2. ОБЈЕКАТ ПРИХВАТАњА, УТИЦАЈА И НАПАДА. ГруПа Придева тиПа наср-

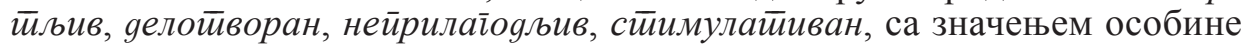
неког појма може се сматрати еквивалентним транзитивним и интранзитивним рекцијским глаголима (СТАнолчић и др. 1989: 218) употребљеним у квалификативном значењу. ${ }^{17}$ Веза придевских и глаголских лексема огледа се у лексичкој семантици, али и у рекцијском потенцијалу који ови придеви преузимају од мотивних глагола.

Придеви овог типа имају облик трпног глаголског придева или су од глагола изведени суфиксом -ив/-љив, којим се изводе придеви ,активног” и „пасивног ” значења (КлАлн 2003: 281-288). Њима је означена особина неког појма $^{18}$ преко имплициране глаголске радње која је усмерена на неки објекат, односно која се врши над неким објектом са обележјем живо(+/-). Уочена су три семантичка подтипа ове врсте допуна. ${ }^{19}$

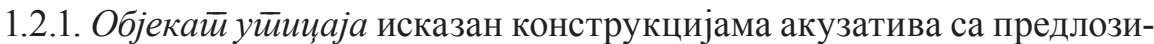

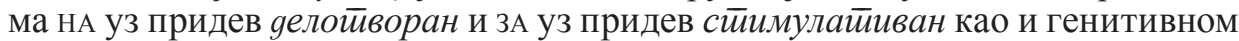
конструкцијом са предлогом против уз придев gелойворан.

У овој књизи сазнаћете на који начин и како припремљен сок од целера може бити делотворан на вас. https://bgonline.rs/

Садашња ниска цена пшенице, којом ратари једва да покривају неке трошкове, није стимулативна за извоз, тврди Дебељачки.

Често се користе и антибиотици широког спектра који су делотворни йройив мнойих йийова бакӣерија.

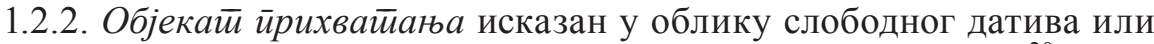

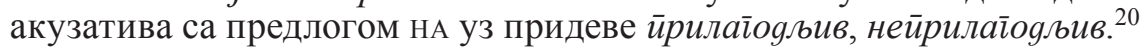

По њеним речима, трговци људским бићима су врло прилагодљиви новим условима...

Он је био сасвим безнадежан лик, доброћудан, али толико неприлагодљив на савремене услове живота да је убијао време углавном у очајању.

17 Оваква могућност постоји када је радња (прошла, будућа или садашња) нереференцијална (Пипер и др. 2005: 348-349), односно када се понавља, врши у низу временских интервала, те се може схватити као особина неког појма.

18 Појам носилац особине може имати ознаку живо(-) ако стоји у метонимијској вези са неком особом или групом особа, односно ако има обележје самоактивност $(+)$.

19 Детаљније о синтаксичким и семантичким карактеристикама акузатива предлошког (нетипичног) објекта видети у: Пипер и др. 2005: 202-205.

${ }^{20}$ Ако носилац особине има обележје живо(-), придев може имати више изражено ,пасивно" значење, а допуна тада има значење намене: Намещӣај йрилайоgљив свакој просторији; Телефон ирилайоgљив потребама корисника. 


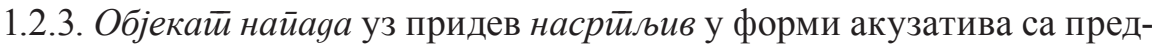
логОМ НА.

Неке расе су рођене да буду насртљивије од осталих (нпр. доберман), неки пси су обучени да буду нарочито насртљиви на сйранще али не и на своје власнике.

1.3. ОБЈЕКАТ КОГНИТИВНОГ ПРОЦЕСА. Придеви којима се некој особи или особама приписује позитиван или негативан став односно мишљење доби-

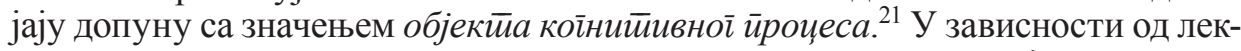
сичке семантике придева и синтаксичко-семантичког односа који се успоставља у придевској синтагми, допуне, које могу бити жива бића, предметни и апстрактни појмови или пак акције, односно реченични садржаји, реализују се у различитим падежним формама и са различитим семантичким обележјима.

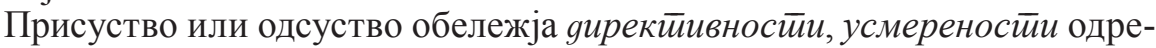
ђује основну разлику међу допунама овог типа. Тако једну групу чине оне којима се исказује познавање или разумевање неког садржаја, при чему је тај садржај обухваћен когнитивним процесом. Ове допуне као релевантно обе-

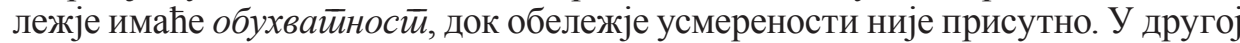
су групи допуне којима се став или мишљење упућују према неком објекту, а релевантно је обележје усмереносиии / gирекииивностии.

1.3.1. Издвојићемо најпре облике допуна са обележјем обухвайностии.

- Допуна у облику слободног генитива уз придеве типа свесйан, несве$c \bar{u} а н$, којом је експлициран објекат у целости обухваћен когнитивним процесом.

Нисам знала тачно зашто то чиним, а истовремено била сам свесна свакой gетиаља.

- Допуна у акузативу са предлогом зА (уз придеве типа ойреgељен, заиниеересован, йријемчив) са ознаком живо(+/-).

Био ми је драг, али не толико да бих остао заинтересован за њеі̄a...

- Конструкција инструментала са предлогом сА 22 (уз придеве типа йомирљив, сайласан, сйоразуман) и предлошким изразом у вези СА (уз придеве типа сумњичав, суздржан) са ознаком живо(-).

У потпуности сам сагласан са слободним избором који предлажу активисткиње покрета.

Директор продаје БMW-а сумњичав у вези са Теслиним Моgелом 3 (https:// naslovi.net)

- Када је допуна у локативу са предлогом о уз придеве типа уздржан, обавешииен, необавешииен, сиооразуман, сайласан, денотирана ситуација

${ }^{21}$ Може се уочити аналогија између глагола интелектуалних и емоционалних процеса и стања и њихових објекатских допуна, с једне стране, и придева истог значења и њихових допуна, с друге стране. О типовима објекта видети и: Арсенијевић 2012.

${ }^{22}$ Конструкција инструментала са предлогом СА у оваквом контексту реализује се у значењу објекта као једном од псеудосоцијативних типова значења. О категорији социјативности видети у: Ивић 1954; ПипеР и др. 2005: 701-710. 
подразумева да носилац когнитивног процеса има позитиван или негативан став о садржају појма, најчешће апстрактног, или пак о радњи исказаној допуном. ${ }^{23}$ Исте семантичко-синтаксичке особине имају и допуне у локативу са предлогом у уз придев саїласан и у генитиву са предлошким изразом у погледу уз придеве типа уздржан, скеййичан и сл.

... јер је једино ова земља до сада била уздржана о йийаюу прослеђивања кандидатуре Србије за чланство у Европској унији...

Иако су аналитичари сагласни у оцени да је трка између Буша и Гора за сада „тесна"...

Аналитичари су, међутим, скептични у йойлеgу скорої коначної gоі̄овора са Париским клубом.

1.3.2. Објекат когнитивног процеса са обележјем усмереностии или gu-

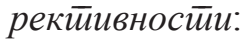

- Допуна у дативу, слободном или блокираном предлогом пРЕмА уз придеве типа крийичан, нейойусйљив, дослеgан, наклоњен, којом се упућује позитиван или негативан став према објекту са обележјем живо(+/-).

Била је беспоштедно критична йрема самој себи.

Словенија остаје доследна стиаву да ће Хрватска морати да попусти пред словеначким територијалним захтевима...

- Допуна у форми акузатива са предлогом у ${ }^{24}$ уз придеве којима је означено

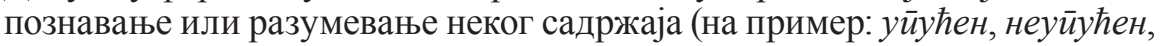
убеђен, уверен, сиіууран и сл.)

Иако, дакле, нисам ни најмање убеђен у ойравgаности таквих одликовања,...

- Допуна у акузативу са предлогом на (уз придеве типа конценитирисан, усреgсређен, иријемчив) са ознаком живо (+/-).

Чак и док је возила, мисли су јој и даље биле усредсређене на кључ који се сада налазио у џепу.

1.4. ОБЈЕКАТ СА ЗНАЧЕњЕМ ПАРТИТИВНОСТИ. СПецифично објекатско значење имају допуне којима се експлицира садржај придева који у инхерентној лексичкој семантици имају семантичку компоненту партитивности и квантификације. Између појма у субјекатској функцији и појма у позицији допуне преко предикације се успоставља однос део-целина. У семантичкој бази ових реченичних структура може се реконструисати глаголски предикат који је

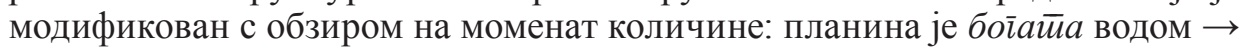
планина има мноі̄o воде, или је компонента квантификације већ садржана у глаголској лексеми: рудник је сиромащин угљем / у угљу $\rightarrow$ рудник не обилује угљем / у угљу. Објекатске допуне овог типа могу се у зависности од

23 Татјана Батистић је употребу ове локативне конструкције уз глаголе поделила у две групе, прву коју чине конструкције репрезенти реченица, и другу коју чине локативне конструкције у функцији предлошког објекта на коме је лоцирана глаголска радња (ВАTISTIĆ 1972: 36).

${ }^{24}$ О разлици између објекта исказаног акузативним конструкцијама са предлозима у и нА писала је Владислава Ружић (2006: 236). 
рекцијског потенцијала самих придева експлицирати у различитим облицима, а при том и субјекатски референт и референт у позицији допуне могу имати ознаку живо (+) и живо(-).

- Допуна у облику слободног генитива из придев $\bar{u} y н$.

Тај млад човек је пун рефлексија, и каквих, за његове године!

То је био неки туђ град пун свет̄а.

То је данас један испроваљиван подрум пун корова и крица од цигли...

- Допуна у облику слободног инструментала уз придеве типа бог̄a $\bar{u}, c u$ ромащан, засићен, изобилан, кризай.

... после свих ових речи још хоће да цени правичност кад свако ко је богат било яухом или имейком...

Путеви који су ишли од трга били су крцати љуgима.

Модеран начин исхране је сиромашан маїнезијумом.

- Допуна у облику локатива са предлогом у уз придеве сиромащан, оскуgaн.

Њен ниски глас био је потмуо и сиромашан у иреливима.

2. ДОПУНЕ СА ЗНАЧЕњЕМ ДРУГОГ УЧЕСНИКА У РЕЛАЦИЈИ. ПрирОДа оДНОса Унутар придевске синтагме условила је издвајање овог семантичког типа допуне иако се као самостално, засебно значење не појављује у нашим рецентним граматикама и студијама везаним за синтаксу и семантику падежа. Други учесник у релацији или други партиципант може имати различите семантичке улоге у зависности од семантике и валентности придева. Релевантно обележје у том смислу јесте рецийрочносй будући да његово присуство у успостављеној релацији имплицира једнаке семантичке улоге првог учесника у релацији у позицији субјекта реченице и другог учесника у позицији допуне придева.

2.1. НосилАц ЈЕдНАКОсти. Први носилац једнакости налази се у позицији граматичког субјекта у номинативу, док је појам са којим се успоставља једнакост у функцији допуне. Оба појма имају исто псеудоагентивно значење: носилаи јеgнакостии, и при том морају имати или ознаку живо(+) или оба појма имају обележје живо(-).

Допуне са овим значењем по правилу су у облику слободног датива или у инструменталу са предлогом СА. Важно је напоменути да готово сви

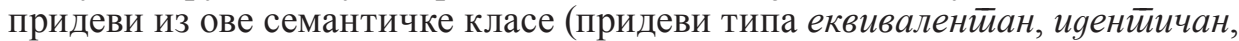
јеgнак, коресйоgенйан, раван и сл.) добијају допуне у обе падежне форме иако се датив и инструментал према семантичким обележјима и положајем у падежном систему српског језика битно разликују. У случају комплементације придева са значењем једнакости у том погледу релевантно је обележје

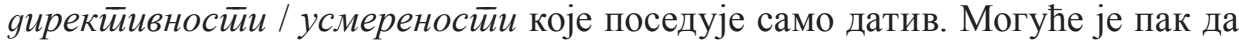
прагматички параметри утичу на појаву једне или друге форме. Ако се приликом успостављања једнакости појам у позицији субјекта схвата у хијерархијском смислу „нижим”, при успостављању једнакости као релевантна прагматичка компонента испољава се ,жеља за равноправношћу” у неком смислу која се усмерава према другом учеснику у релацији у облику датива, 
док, с друге стране, инструментал са предлогом сА у овом контексту имплицира равноправан „партнерски” однос учесника у релацији. ${ }^{25}$

Нема места сумњи да би био поштовања достојна личност, судећи по бујности маште, раван Аніелу Силезију.

Сматрао сам да је капитен раван са остиалима и да на терену не треба да делује наредбодавно...

Придев конкуренйан употребљен као придев којим се исказује једнакост може бити допуњен и конструкцијом у акузативу са предлошким изразОМ У ОДНОСУ НА.

... сматра да су, пре свега, овдашње каматне стопе конкурентне у оgносу на земље из окружења.

Као посебан тип једнакости издваја се однос сличностии будући да не подразумева успостављање реципрочности између два учесника у релацији. Између појма у позицији допуне и појма у позицији субјекта релација се успоставља само на основу неких особина које су карактеристичне за појам у позицији допуне и тај се појам доживљава као „виши“, својеврстан модел којем се тежи. Због присуства обележја усмереносии $и$ уз придеве са значењем сличности везује се првенствено допуна у дативу (придеви типа близак, наличан, йоgобан, сличан, сроgан). Придеви сличан и сроgан могу бити допуњени конструкцијом у инструменталу са предлогом СА, али знатно ређе и то у истом прагматичком контексту као што је био случај код придева са значењем једнакости.

Са дрвета које је изнад моје главе ширило крошњу убрах један крупан плод сличан јабуци...

Зато Акредитациона комисија и захтева да сваки наш студијски програм буде

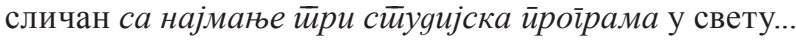

2.2. НосиЛАЦ НЕЈЕДНАКОсти иЛИ суПротности. Реципрочни однос неједнакости или супротности успоставља се између појмова који морају имати исту ознаку живо(+) или живо(-), при чему се појам у позицији допуне уз при-

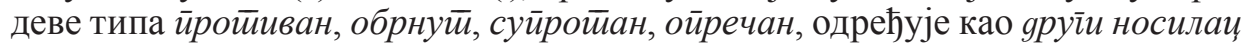

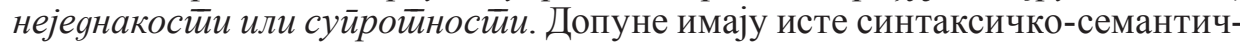
ке карактеристике као оне које се везују уз придеве са значењем једнакости. Ради се, дакле, о допунама у облику слободног датива или инструментала са предлогом СА.

...свака држава чланица чије је национално законодавство неподударно ca üpegложеном изменом може, у року од деведесет дана од дана када то саопшти, ... Ток те књижевне фантазије потпуно је супротан борхесовском фанйасӣичном свет̄⿲y.

Ипак, специфичност саме релације која имплицира неку врсту удаљавања бива маркирана допуном у облику генитива са предлогом од (уз придеве

${ }^{25}$ у Синӣакси савременоїа срӣской језика допуна овог типа у дативу посматра се у оквиру субјекатског значења (Пипер и др. 2005: 181), а допуна у инструменталу блокирана предлогом СА има статус допуне као социјативни инструментал непосредног типа, тзв. „инструментал партнерства” (ПиПеР и др. 2005: 267). 


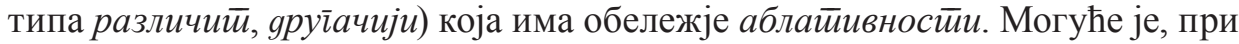
том, да допуна буде у форми акузатива са предлошким изразом у односу нА уколико је семантичка компонента аблативности део лексичке семантике

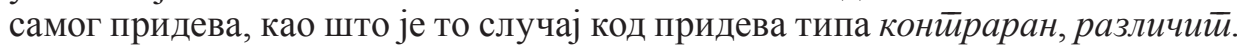

Али резултат који се постиже сасвим је супротан оg оног̆ код Американаца

Али, ако се изузму ове сличности, нови филм је потпуно различит у оgносу на ориїинал.

2.3. ЛокАлизАтор. Одређеним придевским лексемама може се између објекта локализације и локализатора успоставити релација са обележјем

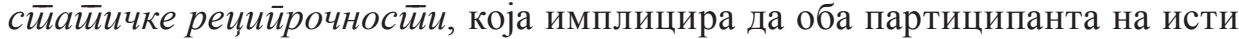
начин учествују у конституисању датог односа (ПиПер 1986: 11). Објекат локализације при том заузима позицију субјекта реченице, а локализатор је у функцији допуне придева.

- Основни облик допуне јесте слободни датив са обележјем сйайичке

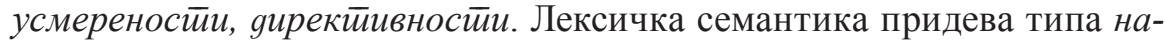
йореgан, йаралелан, симейричан, укључује присуство додатног семан-

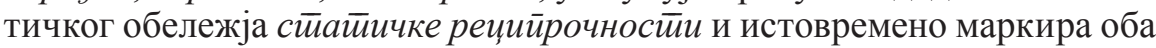
учесника у релацији као појмове са обележјем живо(-).

... требало је да поступак буде обрнуто симетричан ономе којим би се послужила наука...

- Слободни датив уз придеве овог типа могуће је заменити акузативом са предлошком конструкцијом у односу нА будући да и она као релевант-

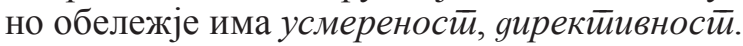

Ипак се у нашим разговорима понекад јављала мисао да свет у целини, дакле, космос, не мора бити симетричан у оgносу на ойеращије под којима природни закони остају непромењени.

- Ако је допуна конструкција инструментала са предлогом сА, обележје усмерености изостаје, чиме се у први план ставља равноправан однос учесника у релацији.

Основа палате је симетрична са среgищњим корӣусом и gва бочна крила.

- Када учесници у овој врсти просторног односа, означеној придевима типа йрийијен и йриљубљен, имају обележје живо(+), локализатор је исказан допуном у облику акузатива са предлогом уз.

То је ово исто осећање што је сада прожима до сржи док дете сиса на њеним грудима припијено уз юу...

2.3.1. Просторни однос без обележја рециитрочностии подразумева смештање у простор објекта локализације са обележјем живо(+/-), који у реченици има субјекатску функцију, док је податак о локализатору са ознаком живо(-), односно о оријентиру у односу на који се одређује положај објекта локализације, експлициран као допуна придеву. Врста просторног односа и експликација различитих синтаксичких облика и семантичких карактеристика допуна условљена је лексичком семантиком придева. 


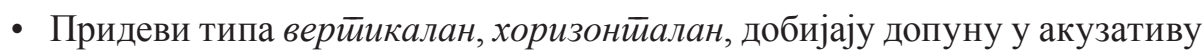
са предлошким изразом у односу нА са значењем посредне просторне локализације.

Горња даска се прави од смрче која има милиметарске годове и они строго морају да буду вертикални у о оносу на gоњу даску.

- Конструкцијом акузатива са предлогом уз експлицира се локализатор успостављеног просторног односа исказаног придевима йрийијен и $\bar{u}$ риљубљен. ${ }^{26}$ Локализатор тада има значење посредне просторне локализације са обележјем посредне просторне удаљености типа проксималност (непосредна близина) (ПиПер и др. 2005: 216).

Фабрис оста непомичан и не дишући; стајао је припијен уз оіромне рещееике свога прозора.

- Придеви типа фунgиран, заснован ${ }^{27}$ добијају допуну у локативу са предлозима нА и у са значењем непосредне просторне локализације.

Коначно мишљење истражне комисије ће бити засновано на йрихваћеним научним иринцийима.

... састављена је од три блока чији су темељи самостални, али спојени гредама, и, како се то каже, фундирани у слоју леса ...

- Допуна у облику генитива са предлогом од и примарним обележјем аблативностии уз придеве типа яалек, неразgвојан, нераскияив, уgаљен и сл. има значење удаљавања, одвајања или издвајања у физичком или у психичком, емотивном смислу. По правилу оба учесника у релацији имају обележје живо(-), међутим, ако се нека особа придевима ойуђен и слобо gан доводи у ову врсту односа са другим појмом, онда он може имати и обележје живо $(+)$ и обележје живо(-).

Уколико је булбус 2 цм удаљен оg руба поља добије 10-20 P. (https://books. google.rs/)

... подвлачи разарајуће ефекте османске окупације Угарске, сматрајући их нераздвојивим оg йурской освајања уопште.

... модерни човек отуђен оg ярущиива и своје йраве ӥрироgе... (https://books. google.rs/)

Раније је он био отуђен og Боїa,... (https://books.google.rs/)

2.4. НоСИЛАЦ ДРУШТВЕНОГ ИЛИ НЕКОГ ДРУГОГ ТИПА ОДНОСА. ПридевскИм Лексемама типа близак, инйиман, комйлеменииаран, неразявојан, несйојив, може бити исказан непосредни социјативни однос ${ }^{28}$ типа партнерства који је у зависности од лексичке семантике придева одређен према квалитету или пак интензитету.

${ }^{26}$ Овај однос успоставља се између појмова са обележјем живо(-). Уколико учесници у релацији имају ознаку живо(+), остварује се узајамни, реципрочни однос, те допуна припада локализатору субјекатског типа.

27 Ови придеви заједно са својим допунама могу образовати просторне метафоре са значењем „налазити се на добро постављеном темељу или основи”.

${ }^{28}$ О значењу социјативности видети у: Ивић 1954: 164-194; ПиПЕР и др. 2005: 264-271; ПиПЕР и др. 2005: 701-706. 
- Како денотирана ситуација подразумева равноправан однос партиципа-

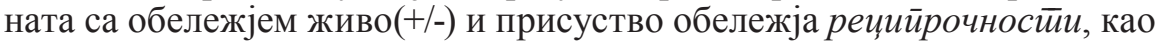
протопипични облик допуне појављује се инструментал са предлогом СА.

Један сведок, који је некада био близак са осуђенима, изјавио је током суђења... И док је расправа о томе да ли су ове превентивне мере инкомпатибилне $c a$ међунарояним gийломайским иравом још увек у току,...

- Допуна може бити и у облику слободног датива (уз придеве типа близак,

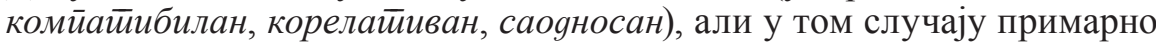

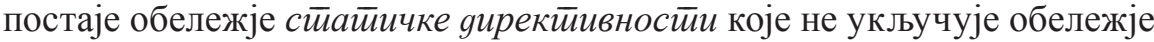
рецийрочностии. Овај облик допуне подразумева да се други учесник у релацији вреднује као „хијерархијски виши“, надређен у неком смислу. Ипак, реципрочност може бити присутна, али то зависи првенствено од прагматичког контекста, ${ }^{29}$ док је код придева типа саоgносан то условљено лексичком семантиком придева.

... у то време још био близак са генералом Џунковским, који је пак био још увек

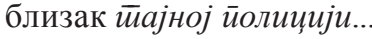

... под условом да се изгради савремена инфраструктура и пословни амбијент компатибилан евройским сйанgаряима...

Лик, као такав, саодносан је йрволику и њиме се свети. (https://poslanica.weebly. com/ikone.html)

- Акузатив са предлошким изразом у односу на може се појавити као алтернативна форма дативу будући да обе структуре имају обележје

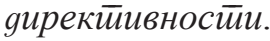

Што се тиче признања које је и сам понео, каже да је то нешто велико и неупоредиво у ояносу на сва gосаяашњ и иојеgиначна и клуйска йризнања, посебно за некога коме спорт значи живот.

2.4.1. Придевима исказан друштвени положај или неки социјално-психолошки однос који подразумева постојање хијерархизације учесника типа надређеност/подређеност, одређује перспективизацију реченице у којој партиципанти заузимају позицију субјекта и допуне предикату. Допуна има примарно значење локализайора, односно у овом контексту, значење gруїо носиоц̧а социјалноі̄ оgноса, али са̂м међусобни однос учесника (надређени/ подређени) зависи првенствено од лексичке семантике придева. Примарно семантичко обележје јесте усмеренос $\bar{u} / g$ иек $\bar{u} и в н о с \bar{u}$, те је отуда други партиципант исказан падежним формама које то обележје имају, при чему оба учесника морају имати или обележје живо(+) или живо(-).

- Допуна у облику слободног датива уз придеве типа наgређен, йоgложан, йорређен.

Два чиновника нужно исходе из трећег који им је надређен, и стоје с његове леве и десне стране.

${ }^{29}$ У примерима који следе прагматички контекст указује на узајамност односа блискости:

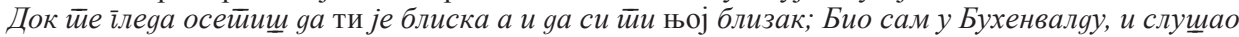

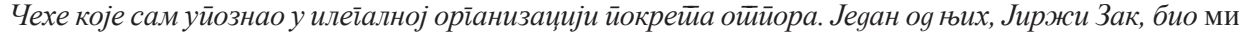
је веома близак. 
... пловеће дизалице и остала пловила код којих је пловидба подређена ґиховој ілавној функцији...

- Допуна у облику акузатива са предлошким изразом у односу нА уз придеве типа наямоћан, суӣериоран, инфериоран.

Ерић је само у почетном сету била инфериорна у ояносу на америчку врщинакињу, да би у наставку меча преокренула резултат.

- Допуна у инструменталу са предлогом нАд уз придеве типа нagмoћaн, суйериоран.

Његова војничка генијалност заснивала се и на широкој култури по чему је био супериоран наg gруіим влаgарима тог времена.

2.5. НосилАц осоьине. Партиципанти који се доводе у релацију помоћу

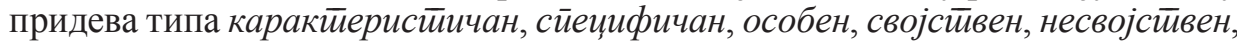
представљају носиоца особине, који може бити живо биће, конкретни предмет, процес или радња, и особину схваћену као карактеристичну појединост чијим се издвајањем карактерише носилац особине. Распоред партиципаната, односно перспективизација реченице маркирана је лексичком семантиком придева, тако да се у позицији субјекта налази податак о карактеристичној

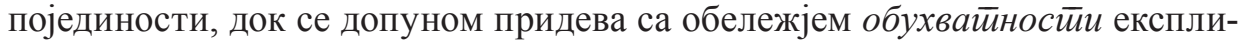
цира податак о носиоцу особине.

- Прототипични облик допуне са значењем носиоца особине јесте акузатив са предлогом зА. Међутим, придеви типа својстивен, особен, несвојсӣвен, као алтернативни облик допуне могу добити и слободни датив уколико

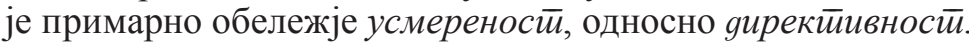

У језику је отелотворена представа света специфична за нарog који се служи одређеним језиком.

... лично сматрам да почетке енглеске индустријске револуције подржава раст особен за Сӣари йореgак.

... гегајући се и љуљајући се, изводио је оне нарочите покрете који су својствени њейовом рояу.

\section{3. Допуне експликативног типа}

3.1. РАДњА МОДИФИКОВАНА УПРАВНИМ ПРИДЕВОМ. У великом броју случајева придевске лексеме имају функцију квалификатора реченичног садржаја исказаног допуном у виду клаузе или пак номинализоване структуре. Иако је наша пажња усмерена првенствено ка синтаксичким и семантичким карактеристикама допуна, класификацију допуна извршићемо према семантичким карактеристикама придева, односно према начину на који квалификују дати садржај.

3.1.1. ДОПУНЕ ПРИДЕВИМА СА ЗНАЧЕњЕМ ДЕОНТИЧКЕ МОДАЛНОСТИ. ${ }^{30}$ ДоПУНОМ се експлицира радња коју је нека особа или неке особе обавезна да изврши. Сама радња је схваћена као мање или више обавезујућа, што је условљено степеном спољашње принуде.

${ }^{30}$ O категорији модалности видети у: Пипер и др. 2005: 637-649; ZveкIĆ-DuŠANOvić 2011; 2019; Киш 2017; 2018; 2019. 
У савременом српском језику неколико је придева којима се на овај начин квалификује ситуација, односно радња, исказана допунском клаузом, инфинитивом ( $у у ж а н,{ }^{31}$ обавезан, йозван, уйућен) или пак девербативном именицом у акузативу са предлозима нА (уз придеве обавезан и уйућен).

По пријему предлога за извршење одлуке којом је извршни дужник обавезан на исйуњење неновчане обавезе.

3.1.2. ДОПУНЕ ПРИДЕВИМА СА ЗНАЧЕњЕМ ОПТАТИВНЕ МОДАЛНОСТИ. ОВај ТИП модалне квалификације упућује на постојање или непостојање жеље, воље да се изврши нека радња.

- Најчешћи облик допуне јесте конструкција акузатива са предлогом зА Уз придеве типа оран, заинйересован, невољан, ойреgељен, односно са

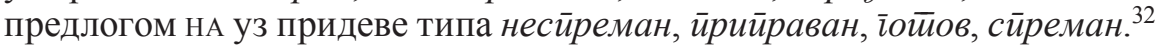

Денис Шефик такође није био оран за иричу.

Петар је знао да је то поуздан знак да се у Григорију кува и да је готов на сваку rygocī.

- Група придева са значењем оптативне модалности (жељан, жуgан, йла-

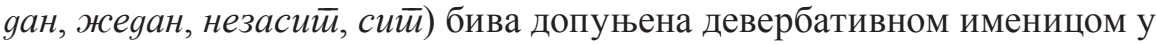
генитиву или пак правом именицом у генитиву у значењу објекӣ $а$ жеље

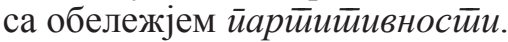

Увек су жељни разі̄овора о тој теми.

А такви ће људи - наставих ја - као и они у олигархији бити жељни новца. Ђаци су били жељни своїа учийеља свакога дана.

- Када је у односу придева и комплемента присутно обележје аблайивно$c \bar{u} u$, допуна је реализује у облику генитива са предлогом од.

Мој тим и ја смо уздржани оg било каквих изјава овакве врсте.

- Насупрот томе, придеви склон и несклон у свом семантичком садржају

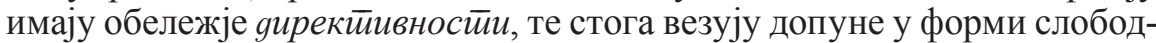
ног датива. ${ }^{33}$

${ }^{31}$ Придев gужан према основном значењу припада класи придева са значењем деонтичке модалности (1. а. који има дужност, обавезу, б. који је приморан, принуђен, обавезан [наведено према Речнику срӣскохрвайскойа кьижевной језика (1967-1976)]) и тада регира допунску клаузу или инфинитив. У свом другом значењу (2. који има дуга, који је обавезан платити,

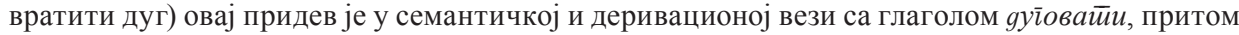
и глагол и придев имају исти рекцијски потенцијал - уз себе везују две објекатске допуне, индиректни објекат у дативу и директни објекат у акузативу (б и о с а м д у ж а / д у г у е м некоме нешйо). Допуна у акузативу само је имплицирана ако се ради о новцу, или се, уколико је у питању нека врста обавезе, експлицира сентенцијалном формом, односно номинализованом структуром: Остао сам му дужан за нека галебова јаја; Ко је коме дужан извињење / ga ce извини? (https://www.nedeljnik.rs).

32 Уз придеве несиреман, йрийраван, сииреман везују се обе предлошке конструкције.

33 У корпусу су уочени примери допуне у форми датива са предлогом кА које се могу одредити као супстандардне: ... у Србији gо саgа није рађено исйраживање о йоме колико су

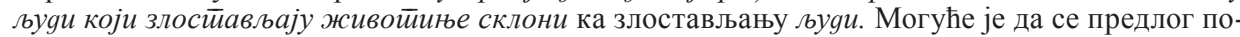

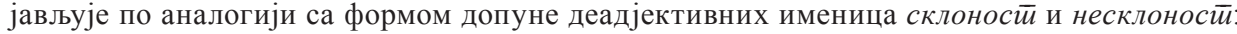

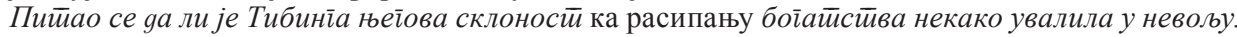


На другој страни, несклон вођењу политике он није могао политички осмислити програм свог покрета.

... у Србији до сада није рађено истраживање о томе колико су људи који злостављају животиње склони ка злостиављању људи.

3.2. ДОПУНЕ СА ЗНАЧЕњЕМ НОСИОЦА КОРИСТИ И ШТЕТЕ. ПрИДеВИ ТИПа кори-

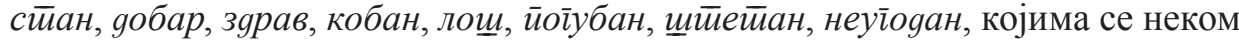
предметном или апстрактном садржају приписује особина типа „утицати (не)повољно на некога или нешто" као допуну могу добити конструкције акузатива са предлозима зА и по којима се исказује носилац користи, бенефицијент, и носилац штете, инкомодент, који могу имати обележје живо(+/-). Иако су ове конструкције синонимне, предлог зА чешће се среће ако се ради о бенефицијентној ситуацији, предлог по је, с друге стране, фреквентнији у инкомодентној ситуацији (ПиПеР и др. 2005: 211).

Боравак на овој планини је зато вишеструко користан за све болеснике, чак и за оне који се припремају за операцију. ${ }^{34}$

... глобализација неумитан светски процес који је стога не само незаустављив

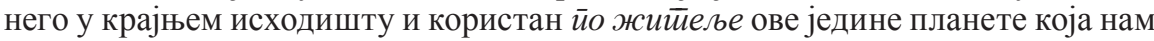
стоји на располагању.

Познато је да су газирана пића штетна йо зgравље.

- Само по изузетку, као допуна придеву користиан, појам са значењем носиоца користи исказан је слободним дативом.

Одустао је од свог романескног првенца и решио да једном у животу буде практичан, односно користан себи и својој йороgиųи.

3.3. ДОПУНЕ СА ЗНАЧЕњЕМ НАМЕНЕ. Као Посебан семанТичКи ПоДТиП изДвајамо допуне са значењем намене. ${ }^{35}$ Носилац особине исказане придевом јесте неки предметни или апстрактни појам ${ }^{36}$ чије се особине вреднују позитивно или негативно што га чини подогним за одређену намену, односно употребу у некој ситуацији, домену живота, акцији експлицираној допуном придева. Допунска конструкција имплицира реченични садржај, те се по правилу гради од номинализованих структура или правих именица са обележјем живо(+/-) употребљених као кондензатори реченичног садржаја.

- Прототипична форма допуне овог типа јесте конструкција акузатива

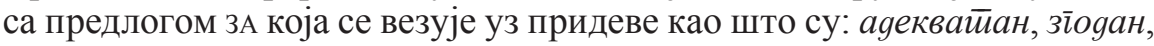

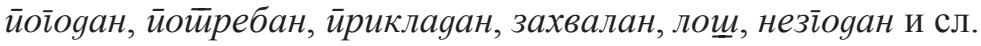

Књига се завршава још једним клишеом згодним за йоgсмех.

${ }^{34}$ Уколико допуна придевима типа gобар, корист̄ан и сл. имплицира реченични садржај, онда је допуном исказана намена појма носиоца особине са ознаком живо(-): Рузмарин је веома

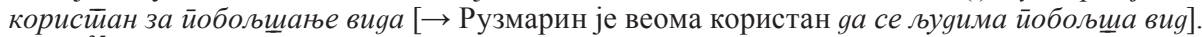

${ }^{35}$ О значењу намене видети у: СтевАновић 1961; КовАчевић 1989; 1992; Арсенијевић 2003; ПиПер и др. 2005.

36 Уколико носилац особине има обележје живо(+), значење исказа и саме допуне се мења, те тада говоримо о интенционалном значењу - нека особа се оцењује као погодна или непогодна према својим особинама за остварење одређеног циља или намере: Пера је йо̄̄ogaн за pag y сменама; Швајцарац је сматрао да овај човек никако није погодан за мене $[\rightarrow$ овај човек није погодан gа ја сарађујем са юим]. 
Представили смо „лаган” приступ локализацији који је погодан за мале језике [ح приступ је погодан ga іа йрименимо на мале језике].

Мисли су му или несувисле или неприкладне за gецу и омлаgину. [ح мисли су му неприкладне ga их чују gец̧а и омлаgина] $]^{37}$

- Придеви типа нейриличан, ӣō̄ogaн, йриклаgан, йримерен као алтернативни облик допуне са значењем намене могу добити и слободни датив поред акузатива са предлогом зА.

... навикли смо да породично зимујемо у неком од тамошњих ски центара који су веома организовани и прикладни нащем буцет̄y.

- Као допуна придеву gелойворан може се појавити конструкција генитива именице са обележјем живо $(+)$ и предлогом код која је семантички еквивалентна акузативној конструкцији са значењем намене.

Диуретици су посебно делотворни коg срчаних болесника [за срчане болесике I ga их узимају срчани болеснищи] јер код њих ублажавају појаву отеклих зглобова и задиханости.

3.4. ДОПУНЕ СА ЗНАЧЕњЕМ НАЧИНА ВРШЕњА РАДњЕ ИЛИ КВАНТИФИКАЦИЈЕ РАДњЕ. Одређени придеви којима се неком предметном или апстрактном појму приписује особина еквивалентна глаголској радњи могу регирати допуне којима се конкретизују семантички садржаји у вези са околностима под којима се имплицирана радња врши. Тако се експлицира начин вршења радње исказане придевима типа gељив, нерастиављив, средство типа омогућивач уз придев gељив, или се имплицирана радња исказана придевима несвоgљив и своgљив квантификује у смислу лимитативности, ${ }^{38}$ ограничавања на неку меру.

- Основни облик допуне јесте акузатив са предлогом нА.

Ево и једног лепшег примера који говори о томе колико је језик несводљив $н а$ јеуно значење и јеgну йоруку.

- Придев ирименљив као допуну добија и акузатив са предлогом зА.

Да ли данас постоји само један, универзални модел демократије применљив за сва ярушитвва...

- Уколико је придев gељив део појмовно-терминолошког апарата математичког дискурса, као допуну добија инструментал са предлогом сА или слободни инструментал ако је допуна именица број са одговарајућим квантификатором.

Број је дељив са gевет̄ ако је збир његових цифара дељив са девет.

Један цео број дељив је яруіим ичелим бројем ако је остатак тог дељења једнак нули.

3.5. ЗНАЧЕњЕ КВАНТИФИКАЦИЈЕ. ПридеВИ gареж љив, $\underline{w \kappa р} \bar{u}, \underline{u} \bar{u} y p$ Тек уПотребљени заједно са допунама добијају семантичку улогу квантификатора

37 Уколико је допуном исказан појам са обележјем живо(+), може доћи до интерференције са значењем носилаи користии или щйетеие. Међутим, због могућности реконструкције

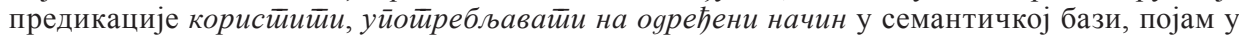
функцији допуне схвата се као айенс имплициране радње, а као примарно значење допуне реализује се значење намене.

${ }^{38}$ Видети: Пипер и др. 2005: 229. 
мноїо и мало радње исказане допуном у облику локатива са предлозима у и НА.

... био је нарочито дарежљив у йомайању и йоgизању нових цркава у Србији и у Светој Гори. [мноїо је помагао и подизао нове цркве]

Свакако ће се тај џентлмен, тако шкрт у корачању, зауставити онде. [који мало корача]

Пошто су модни зналци прилично шкрти на саветиима који се односе на боје и дезене, ту можете пустити машти на вољу. [модни зналци мало саветују / дају савете]

... остао је прилично штур на речима. [наставио је мало да говори]

4. ДОПУНЕ СА ЗНАЧЕњЕМ СИТУАЦИОНОГ ОКВИРА. ДоПУНама овог тиПа конкретизује се временско-ситуациони оквир, домен живота у којем се остварује, испољава придевом исказана особина појма у позицији граматичког субјекта. У позицији допуне по правилу је девербативна именица или права именица која у датом контексту имплицира предикацију. У зависности од лексичке семантике придева носилац особине може имати обележје живо(+) или живо(-).

- Допуне у локативу:

Допуна у облику локатива са предлогом У уз придеве типа gелойворан, ефикасан, искусан, исиирајан, комойан, йосӣојан, умерен, усиешиан, недосле-

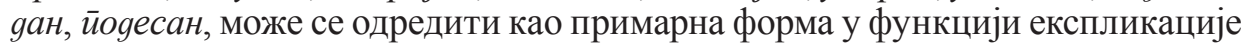
временско-ситуационог оквира у који се смешта, односно у којем се испољава особина носиоца особине са обележјем живо(+) или живо(-). ${ }^{39}$

Ја још нисам видео да је неко тако умерен у личним йрохиевима...

Да и не говоримо о томе да су Ахтисари и Роан недоследни у својој лойици колективне кривице.

Засад је потврђено да је коктел три аминокиселине делотворан у ӣроgужењу живота мишева.

- Допуне у генитиву:

Конструкције са предлозима и предлошким изразима у погледу / нА пољу; носилац особине има обележје живо $(+)$.

Очито сам ових дана, иако неодлучан у йоїлеgу оgласка на одмор, у себи направио списак оног што је неопходно.

Феминисткиње активне на йољу анӣройолоїије такође су се бавиле питањем матријархата.

Конструкције са предлозима против ${ }^{40}$ уз придев ефикасан и код уз придев усйещан, заменљиве су конструкцијом локатива са предлогом у као

\footnotetext{
${ }^{39}$ Конструкције генитива блокираног различитим предлозима са овим значењем према својим синтаксичко-семантичким карактеристикама еквивалентне су овој локативној конструкцији. Остали облици допуна маркирани су додатним семантичким обележјима: допуне

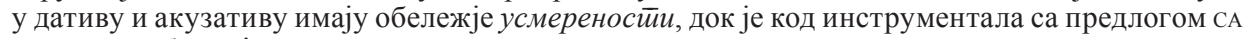

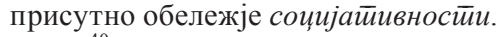

${ }^{40}$ Примарно значење генитивне конструкције са предлогом против јесте значење $о \bar{u} о-$

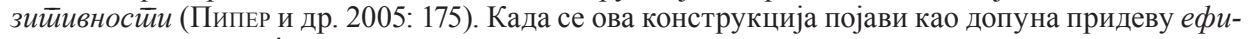
$к а с а н$, она кондензује клаузу са имплицираним глаголским предикатом са значењем супротстављања, а при том је придев истовремено оријентисан и ка субјекту и ка имплицираном
} 
прототипичним обликом допуна овог семантичког типа; носилац особине има обележје живо(-).

ХРТ терапија може да буде веома ефикасна йройив неких симӣ̄̄ома менопаузе.

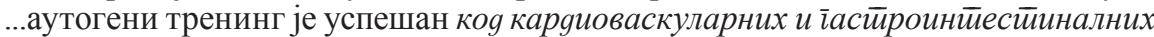
ироблема. [успешан у лечењу кардиоваскуларних и гастроинтестиналних проблема].

Слободни генитив са обележјем $\bar{u} а \bar{u} и \bar{u} и в н о с \bar{u} и$ има функцију допуне придевима вреgан, gостиојан, неgост̄ојан. Допуном се експлицира ситуација, у којој се улога носиоца особине са обележјем живо(+/-) оцењује као (не)значајна или (не)важна.

Ма колико Урас био вредан йрезира, он је ипак представљао други свет...

Дивљења вредан проналазак, ако би се употребио за скретање речних токова...

- Допуне у дативу:

Слободни датив уз придеве вичан, gораст̄ио када носилац особине има обележје аниматности, а допуном се експлицира ситуација, активност за коју нека особа има адекватне особине, односно способности.

Деца су врло вична слеgећој вежби:...

... добила једну поштену, храбру, умну жену великог срца, која не припада ни-

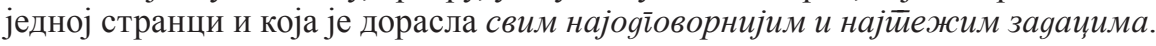

- Допуне у акузативу:

Конструкција са предлогом зА може се појавити као допуна придевима

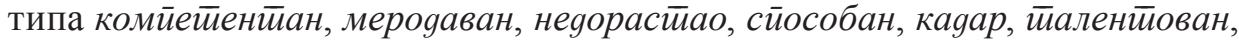
важан, заслужан, значајан, бийан, оgіоворан, када се њима вреднује способност носиоца особине са обележјем живо $(+)$, или се пак процењује улога, степен важности и утицај носиоца особине, који овога пута може имати обележје живо(+/-). Самом допуном експлицира се ситуација, активност у којој се (не)испољавају наведене карактеристике.

Он је био више него снажан и способан за изванреgне йоgвиіе снаге.

И онда си схватила да си талентована за йлес?

...jедини је наш научник међу великанима заслужним за развој рачунарства у свету...

Стабљике трске су заслужне за ущū̄ege топлоте и очувану хладовину.

Конструкција са предлогом нА уз придеве типа йрименљив, нейрименљив има функцију експликације временско-ситуационог оквира у којем се испољава особина појма са обележјем живо(-), а који се оцењује као (не)корисно средство у именованој ситуацији.

Сетимо се данас ове пророчке анализе Грамшија из тридесетих година, сасвим применљиве на срйску, али и реїионалну акйуелну кризу.

Случај подељене Немачке неприменљив је на Србију и Космет̄.

- Допуне у инструменталу:

предикату: [ $\rightarrow$ ХРТ терапија је врло е ф и к а с н а каg се бори йройив неких симййома менойаузе / ХРТ терапија се врло е ф и к а с н о бори йройив неких симйойома менойаузе]. 
Допуна овог семантичког типа уз придеве типа gобар, вещuй, уколико носилац особине има обележје живо $(+)$ може бити исказана именицом у инструменталу са предлогом СА.

Богата клијентела од Денвера до Јерусалима, наоружана озбиљним новцем и вешта са карайима, одједном више није сигурна да ли да се шепури својим дијамантима!

5. ДОПУНЕ СА ЗНАЧЕњЕМ УЗРОКА. Каузални однос укључује постојање најмање три елемента: две ситуације, једне узрочне (она је заправо полазна, исходишна) и друге последичне (она је крајња), и једносмерног агентивног, узрочно-последичног односа између њих (ПиПеР и др. 2005: 788). Узрочна ситуација својим деловањем другу ситуацију ствара, мења или укида. Када се посматрају допуне придева са значењем узрока распоред ових елемената по правилу подразумева да се у позицији граматичког субјекта реченице налази податак о, условно речено, последици, сам однос успоставља се придевима одговарајуће семантике у позицији лексичког дела предиката, док се податак о каузатору смешта у позицију допуне предиката, односно придева у његовом саставу. Ситуација која настаје као последична по правилу јесте неки физиолошки или психолошки процес који настаје деловањем каузатора на неку особу или особе. Носилац или доживљавач насталог психофизиолошког процеса са обележјем живо(+) јесте заправо „последица” деловања каузатоpa, те се смешта у позицију субјекта реченице. С друге стране, семантичке карактеристике допуна са каузалним значењем зависе умногоме од природе појмова који ту улогу имају и од начина на који делују на неки појам, те се с обзиром на те околности уочавају конструкције са значењем узрока типа

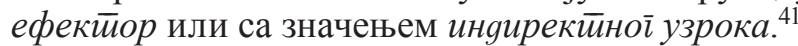

Узрок типа ефектор може бити референт са ознаком живо(+) или пак чешће са ознаком живо(-) који својом природом или појавом изазива спонтану реакцију, без воље и свесне контроле од стране носиоца психофизиолошког процеса.

- Допуна у форми генитива са предлогом од уз придеве типа изможgен, изнурен, зависан, независан најчешћи је облик допуне са значењем ефектора.

41 Директни или активни узрок имамо у ситуацији када узрочне конструкције садрже

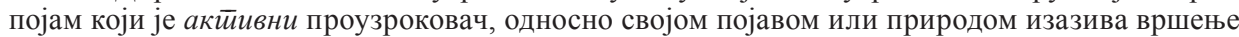
радње, или даје подстрека за вршење те радње, а индиректни или пасивни када се дати појам схвати као нешто што само индирекӣно има везе са изазивањем неке радње, у том смислу да се појављује као прва, почетна појава у низу збивања која су довела до вршења дате радње. У зависности од природе и начина на који делује активни проузроковач, разликују се два подтипа: појам изазивач или ефекйор неког стања који својом природом и својом појавом изази-

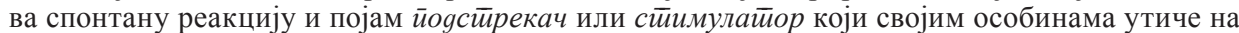
вољни моменат, који $\bar{u} о g c \bar{u} и ч е ~ н а ~ в р ш е њ е ~ р а д њ е ~(о б и ч н о ~ с е ~ р а д и ~ о ~ у н у и ̆ р а щ и н и м ~ \overline{и о б у g а м а ~}$ које доводе до реализације неке акције). Наведену типологију Милке Ивић (1954) терминолошким прецизирањем употпунио је Милорад Радовановић, уводећи термине директни узрок типа ефектор и стимулатор и индиректни узрок (RADOVANOVIĆ 1977). O карактеристикама узрочног значења и језичким средствима његовог исказивања видети у: ГортАн-Премк 1964; KovAČEvić 1988; BugARSKi 1999; АлАновй 2011. 
Већ су неке животиње, изнурене og іллаgи и жеђи, остале на путу.

Тада овај доминантни „тиранин” показује колико је он у ствари зависан $o g$ йарйнерке, колико је слаб, колико се лоше осећа када га је напустила.

- Допунама у облику слободног инструментала и конструкција са предлозима ПРЕД, НАД уз придеве типа равноgущан, заgовољан, занесен, засићен, измучен, зайанен, изнурен, ойиерећен, йасиониран, такође се експлицира изазивач неког психофизиолошког стања или расположења.

Онако блед, као изнурен неком болещћy, Петар је пред њим стајао и тужно га посматрао.

Када је био млад (и сада је) био је пасиониран ексйремним сйорйовима.

Нема тог уметника који остаје равнодушан йреg жийним йољима.

Катарина је понекад остајала запањена $\mathrm{kag}$ смелощћy својих претпоставки, надала се - или бојала - да је отишла предалеко...

- Придев овисан као допуну овог типа везује уз себе конструкцију локатива са предлогом о.

Да, био сам овисан о кокаину. (https://time.rs/)

Каузатор, с друге стране, може само индиректно имати везе са изазивањем неког психофизиолошког процеса, стања, распложења или пак ситуације, те представљати њихов повод, односно мотивацију за њихов настанак.

- Такав је случај са дворекцијским придевима блаїоgаран и захвалан ${ }^{42}$ чија је прва допуна објекат упућивања, док друга допуна у акузативу са предлогом зА или у локативу са предлогом НА има значење индиректног узрока.

Извукао ми је живу главу и ја ћу му вечито бити захвална за йо.

У таквим приликама мој его се смањује до величине пужа, што не значи да им нисам захвална на йозивима.

Перспективизација реченице у којој се исказује узрочно-последични однос може подразумевати и другачији распоред учесника у сутуацији. Уколико се каузални однос исказује придевским лексемама типа крив, ogīoворан, caоgīoворан, заслужан, значајан, каузатор са обележјем живо $(+)$ биће смештен у позицији субјекта реченице, док ће у функцији допуне именског предиката бити конструкција акузатива са предлогом зА и значењем последице акције или деловања појма у функцији субјекта реченице.

Лугар се сигурно досетио да је Каро био крив за смрй лосове женке.

Невладине организације су заслужне за йобеgy опозиције на септембарским изборима.

6. ЗАКључАК. Придеви у савременом српском језику који захтевају неку врсту конкретизације и употпуњавања значења везују уз себе допуне у пет основних значења, односно семантичких функција. То могу бити допуне са

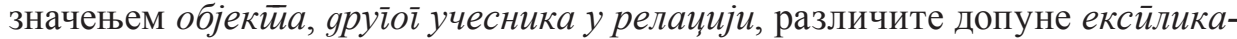

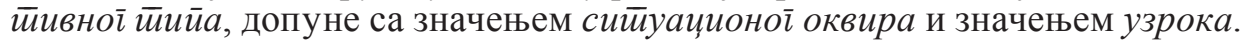

42 О конструкцији локатива са предлогом нА у функцији допуне глаголу захвалит̄u се видети у: ВАтISTIĆ 1972: 40. 
У оквиру издвојених семантичких функција могуће је разликовати подтипове одређене присуством релевантних семантичких обележја као што су анимай-

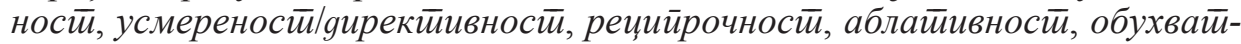

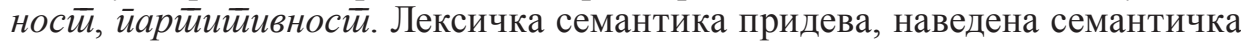
обележја, али и прагматички контекст у појединим случајевима, условљавају експликацију допуна одређеног семантичког типа и морфосинтаксичких карактеристика. Анализа је показала да допуне могу имати облик слободног генитива, датива и инструментала, односно могу бити у облику предлошко-падежних конструкција генитива (са предлозима пРотив, поРед, од, код, СПРАМ, У ПОГЛЕДУ, НА ПОљУ), даТива (са ПредлоГОм ПРЕМА), акУзаТива (са предлозима ЗА, НА, у, уз, у односу НА, по), инструментала (са предлозима СА, у ВЕзи СА, ПРЕД, НАД) и Локатива (са предлозима у, о, НА), а оно што је свакако веома важно јесте да је могуће издвојити прототипичне облике допуна за уочене семантичке типове и подтипове допуна.

\section{ИЗВОРИ}

Речник срӣскохрвайскоїа књижевной језика, I-III. Нови Сад - Загреб: Матица српска - Матица хрватска, 1967-1969; IV-VI, Нови Сад: Матица српска, 1967-1976.

SrpKor2013: Duško Vitas, Miloš Utvić. Korpus savremenog srpskog jezika (verzija SrpKor2013) Copyright Grupa za jezičke tehnologije Univerziteta u Beogradu.

\section{ЦИТИРАНА ЛИТЕРАТУРА}

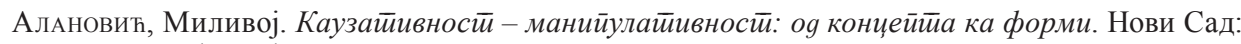
Филозофски факултет, 2011.

Антонић, Ивана. Синтакса и семантика датива. Јужнословенски филолої LX (2004): 95-97.

Антонић, Ивана. Синтакса и семантика предлога йрема. Зборник Майице срйске за филолойју и линіввистиику LIV/2 (2011): 161-178.

Арсенијевић, Нада. Акузатив с предлогом у савременом српском језику (I). Зборник Майице срйске за филолойију и линіввисииику XLVI/1 (2003): 107-263.

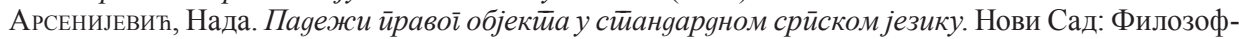
ски факултет Нови Сад - Одсек за српски језик и лингвистику, 2012.

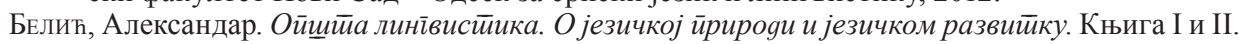
Изабрана дела Александра Белића. Први том. Београд - Нови Сад: Завод за уџбенике и наставна средства - Будућност, 1998.

ВсеволодовА, Майя Владимировна. Теория функиионально-комуникативного синтаксиса. Фрагмент прикладной (педагогической) модели языка. Москва: Издательство Московского университета, 2000.

ГортАн-Премк, Даринка. Падежне и предлошко-падежне узрочне конструкције код Вука. $J y$ жнословенски филолог XXVI/1-2 (1964): 437-457.

Ивић, Милка. Значењ а срӣскохрвайской инстируменйала и њихов развој. Синйаксичко-семан$\bar{u} и ч к а ~ c \bar{u} y g u j a$. Београд: Научна књига, 1954.

Ивић, Милка. Узрочне конструкције с предлозима збо̄, og, из у савременом књижевном језику. Нам језик 5, н.c. 5-6 (1954a): 186-94.

Ивић, Милка. О тзв. 'транзитивним именицама' које означавају људска бића. Нам језик XXXVI, св. 1-4 (2005): 1-5. 
КовАчевић, Милош. Интенционалне конструкције у Доситејеву језику. Зборник Майице срйске за филолоіију и линівисӣику XXXII/2 (1989): 177-193.

Киш, Наташа. Дойуне йрияева у савременом срйском језику. Едиција Е-дисертација, књ. 11, http://digitalna.ff.uns.ac.rs/sadrzaj/2016/978-86-6065-397-2. Нови Сад: Филозофски факултет, 2016.

Киш, Наташа. О степену дезидеративности исказане придевима. Језищи и кулитуре у времену u йростиору VII/2. Снежана Гудирић, Биљана Радић-Бојанић (ур.). Нови Сад: Универзитет у Новом Саду - Филозофски факултет, 2018, 89-97.

КлАлн, Иван. Творба речи у савременом срйском језику. Друіи gео. Суфиксаиија и конверзија. Београд - Нови Сад: Завод за уџбенике и наставна средства - Институт за српски језик САНУ - Матица српска, 2003.

ПипеР, Предраг. Реципрочност и рефлексивност у словенским језицима. Јужнословенски филолої XLII (1986): 9-20.

Пипер, Предраг, Ивана Антонић, Владислава Ружић, Срето ТАнАсић, Људмила Поповић, Бранко Тошовић (у редакцији академика Милке Ивић). Синйакса савременойа срииской језика. Простиа реченица. Београд: Институт за српски језик САНУ - Београдска књига - Матица српска, 2005.

Пипер, Пипер, Иван КлАлн. Нормайивна ірамайика срӣской језика. Нови Сад: Матица српска, 2013.

Ружић, Владислава. Допунске реченице у савременом српском језику (II). Зборник Майице сриеске за филолоїију и линйвистиику XLIX/2 (2006): 103-266.

СтевАновић, Михаило. Проблем глаголског рода и повратни глаголи у српскохрватском језику. Јужнословенски филолоі XXV (1961-1962): 1-47.

Стевановић, Михаило. Савремени срйскохрват̄ски језик (іррамайички систиеми и књижевнојезичка норма). II Синйакса. Београд: Научна књига, 1989.

Станојчић, Живојин, Љубомир Поповић, Стеван Мицић. Грамайика срӣскойа језика. Уибеник за I, II, III и IV paзpeg среgње щиколе. Београд - Нови Сад: Завод за уџбенике и наставна средства - Завод за издавање уџбеника, 1989.

BATISTIĆ, Tatjana. Lokativ u savremenom srpskohrvatskom književnom jeziku. Beograd: Institut za srpskohrvatski jezik, 1972.

Bugarski, Nataša. Uzročna klauza u jeziku Danila Kiša. Зборник Майице срӣске за филолоїију и линївисиичику XLII (1999): 189-217.

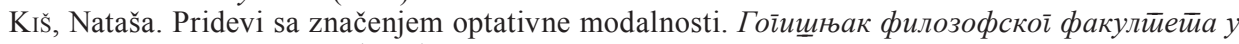
Новом Саgy XLII-1 (2017): 305-320.

KIš, Nataša. Modalnost iskazana deadjektivnim imenicama u romanu NA SUNČANOJ STRANI, Andrićeva sunčana strana. Andrićs sonnenseite. Andrić-Initiative 12. Branko Tošović (ur.). Graz-Beograd: Institut für Slawistik der Karl-Franzens-Universität - Narodna i univerzitetska biblioteka Republike Srpske u Banjaluci - Svet knjige - nmlibris, 2019, 745-760.

KovaČEvić, Miloš. Uzročno semantičko polje. Sarajevo: Svjetlost, 1988.

KovačEvić, Miloš. Kroz sintagme i rečenice. Nastavna biblioteka 118. Sarajevo: Svjetlost, 1992.

Radovanović, Milorad. Imenica u funkciji kondenzatora (II). Зборник Майице срйске за филолоіију и линівистиику XX/2 (1977): 81-160.

Zverić-DušAnović, Dušanka. Modalnost: motivaciona modalnost u srpskom i mađarskom jeziku. Novi Sad: Filozofski fakultet, 2011.

Zverić-Dušanović, Dušanka. Epistemička modalnost u srpskom i mađarskom jeziku. Novi Sad: Filozofski fakultet, 2019. 
Nataša Kiš

\section{SYNTACTIC AND SEMANTIC CHARACTERISTICS OF ADJECTIVE COMPLEMENTS}

\section{Su m m a ry}

The paper presents the results of an analysis of semantic and syntactic characteristics of adjective complements in contemporary Serbian. The main goal is to indicate the semantic functions of these complements, which involves investigating semantic, syntactic and pragmatic parameters thataffect the choice of complements of a certain semantic type and form. The analysis shows that it is possible to single out six basic semantic functions of adjective complements: complements with the meaning of an object or another participant in a relation, complements for concretizing the meaning of the governing adjective, complements denoting situational framework, complements denoting purpose and cause. Within these semantic functions, subtypes are distinguished on the basis of the presence of relevant semantic features such as animation, directionality, reciprocity, ablativity, comprehensiveness, and partitivity. In addition to these semantic features, it is shown that the lexical semantics of adjectives and, in some cases, the pragmatic context also influence complementation and the form of adjective complements.

Универзитет у Новом Саду

Филозофски факултет

Одсек за српски језик и лингвистику

Др Зорана Ђинђића 2, 21000 Нови Сад, Србија

natasakis14@gmail.com
(Примљено: 22. августа 2020; прихваћено: 28. октобра 2020) 